\title{
17 Using the World Wide Web to Research Spoken Varieties of English: The Case of Pulmonic Ingressive Speech
}

\author{
Peter Sundkvist \\ Stockholm University
}

\section{Introduction}

Undoubtedly, one of the most significant developments for human interaction and communication within the last thirty years or so is the internet. Its origins may be traced back to various experimental computer networks of the I960s (Crystal 2013:3). It has since grown by a phenomenal rate: between 2000 and $20 \mathrm{I} 2$ the number of internet users increased by an average of $566.4 \%$ across the globe, and as of $20 \mathrm{I} 2$ $34.3 \%$ of the world's population was estimated to have access to the internet (Internet World Stats 20I2). Partly as a result of its phenomenal growth the internet has also established itself as an important tool and source of information within the fields of linguistics and English studies. While much linguistically-oriented work has focused on features and developments related to the electronic medium of communication itself, inquiry has gradually extended into further domains, as researchers become more creative in exploring the full potential of the internet. In particular, the World Wide Web (WWW), defined as "the full collection of all the computers linked to the internet which hold documents that are mutually accessible through the use of a standard protocol (Hypertext transfer protocol, or HTTP)" (Crystal 2013: I3), has opened up a range of new possibilities with regard to linguistic research. Thus far, however, less attention has been devoted to its potential for research on spoken varieties of English. The aim of this paper, therefore, is to explore the World Wide Web as a source of evidence for a specific feature of spoken language. Drawing upon the fact that very large amounts of audio and video material have become available, through a diverse range of online resources, the aim is to

How to cite this book chapter:

Sundkvist, P. 20 I 5. Using the World Wide Web to Research Spoken Varieties of English: The Case of Pulmonic Ingressive Speech. In: Shaw, P., Erman, B., Melchers, G. and Sundkvist, P. (eds) From Clerks to Corpora: essays on the English language yesterday and today. Pp. 303-32I. Stockholm: Stockholm University Press. DOI: http://dx.doi.org/Io.I6993/bab.q License: CC-BY. 
gather evidence for and provide documentation of a somewhat elusive paralinguistic feature within a set of regional Englishes, which has thus far proved challenging to study by means of more standard methods.

\section{Pulmonic ingressive speech}

Visitors to the Nordic countries are often struck by a curious feature in the speech of the locals. In conversation, Norwegians, Swedes and Danes can frequently be heard drawing their breath inwards, in a manner vaguely reminiscent of a sudden gasp. Although often erroneously interpreted by the uninitiated listener as a sign of sudden ill health or astonishment, this is in fact a well-established paralinguistic feature. The technical term for this phenomenon is 'pulmonic ingressive speech'. Most commonly of course, human speech occurs on an outward airstream, directed from the lungs towards the mouth. The phonetic term for this is pulmonic ('involving lungs') egressive ('outwards') speech. However, it is also perfectly possible to speak on a reverse, inward ('ingressive') airstream, by drawing air into the lungs while speaking. In the Nordic languages, this airstream mechanism is commonly used on short words for 'yes' and 'no', especially when provided as backchannel items in a conversation, when the listener wants to signal to the speaker that he or she is following what is being said. While the many anecdotes of befuddlement on part of newcomers may seem to imply that ingressive speech is restricted to the Nordic languages, it is becoming clear that the phenomenon in fact occurs in a much wider range of languages and language varieties, including several regional Englishes.

At present there is no consensus regarding the cross-linguistic distribution of pulmonic ingressive speech. According to one view it may be found in a wide range of languages, on all continents of the world. Based on an extensive review of various sources, Eklund (2007, 2008) suggests that it has simply gone unnoticed for many parts of the world, and that insufficient effort has been made to compile and compare reports from across the globe. In typological terms, pulmonic ingressive speech is thus seen as constituting a 'neglected universal' (Eklund 2007). However, an opposing view suggests that ingressive speech is geographically restricted. Clarke and Melchers (2005) argue that ingressive speech occurs primarily within a region stretching in the east from the Baltic countries (e.g. Estonia) and westwards over Scandinavia (peninsular as well as insular), northern parts of continental Europe (Germany, Austria), across some regions of the British 
Isles, and finally into Maritime Canada and coastal New England. This pattern finds a ready historical explanation. Pulmonic ingressive speech, it is suggested, was first spread by Vikings from Scandinavia westwards to the British Isles and eastwards to the Baltic countries. Subsequently it was further transmitted across the North Atlantic by Irish and British migrants (Clarke \& Melchers 2005; Shorrocks 2003). From this perspective, pulmonic ingressive speech is considered to be 'typologically highly marked' (Clarke \& Melchers 2005).

While at first sight ingressive speech may merely seem as a quaint curiosity, it soon becomes clear that further investigation into the phenomenon is significant for several reasons. From a general viewpoint it is a feature whose typological status remains to be established. From the present perspective of English studies, its precise distribution among regional varieties of English remains an open question, in spite of the fact that it is reported in several areas. Further insight into the use of ingressive speech among such forms of English may furthermore reveal historical connections among relevant regions. What is more, pulmonic ingressive speech is commonly surrounded by popular mythology. For instance, where it occurs, locals often seem to believe that it is somewhat unique to them and their communities. This, as we will see, appears to be the case for some regional Englishes also.

\section{Pulmonic ingressive speech in regional Englishes: A test case for the World Wide Web?}

One problem which has stalled the study into ingressives is the lack of objective evidence. For many regions where it reportedly occurs there is very little documentation in such forms as audio or video recordings, and the sole evidence consists of informal observation. The absence of data is in many cases not attributable to a lack of trying but to various inherent challenges for data collection. While the most obvious method may seem to be to collect ingressives by recording interviews, such attempts have had rather mixed success. In many cases, the interview situation itself seems to militate against the occurrence of ingressives. It has been argued that pulmonic ingressive speech tends to be used primarily in relaxed, informal situations, and that a level of interpersonal affiliation between the speaker and listener is required (Clarke \& Melchers 2005). Owing to such challenges facing anyone setting out to record ingressives through interviews, pre-existing data sets and corpora would seem like a suitable alternative, perhaps especially for such localities where the inquiry 
into ingressives is at an early stage and simply objectively supported instances would constitute an important step forward. Even for this approach, however, previous researchers report various difficulties, as ingressives seem poorly represented in certain types of existing recordings (cf. e.g. Thom 2005).

A major source of pre-existing recordings is of course audio and visual media. However, it has been suggested that the media may perhaps not be a very good resource for pulmonic ingressive speech. Thom remarks that ingressive speech is used especially by such sections of society which are not well represented in the media - which within this context means primarily elderly, rural speakers - and therefore is bound to be underrepresented in media-based corpora: "[...] it was difficult to find examples of [ingressive speech] in recorded material, either on radio or on television. This was because [ingressive speech] tends to be used in informal situations, and (as I discovered) mostly by groups of people who are rarely seen in the media." (Thom 2005: 28-9). In Swedish (and Finnish), the word jo/ju ('yes') is sometimes pronounced as a voiceless bilabial fricative or approximant, on a pulmonic ingressive airstream. The frequency of this feature appears to increase the further north in Sweden you go (Eklund 2008: 262-263), and it is popularly associated with northern parts. With regard to media, however, Hanell and Salö (2009: I9) claim that "You can actually spend hours among video clips on YouTube where [well-known people from the northern part of Sweden], such as Ingemar Stenmark and Maud Olofsson, go through interview after interview without making a single [jo/ju, bilabial fricative]" (author's translation).

In face of the difficulties in documenting ingressives through more standard methods, it is natural to consider what potential the World Wide Web may offer. Owing to its massive expansion, a wide range of audio and visual material is now available online. This includes not only news broadcasts, documentaries, entertainment etc. but also unedited material posted at sites such as YouTube. The aim of this paper is therefore to provide documentation of pulmonic ingressive speech in regional Englishes, and within the North Atlantic region more generally, based on material accessed through the World Wide Web. As far as has been possible, this is based on publicly available sources, for which URLs are provided; in some instances research data has been utilized as an additional source of information. Secondly, the aim is also to find illustrations of the popular mythology surrounding ingressives on the basis of material available through the WWW. 


\section{Documentation of pulmonic ingressive speech: Audio and video}

The following section provides illustration of the use of pulmonic ingressive speech based on audio and visual data. The focus is on Englishes across the North Atlantic region for which relevant data has thus far been acquired. In addition, examples are offered from certain Scandinavian languages, as well as one speaker from western Canada. Brief extracts of conversations are transcribed and presented; in these, words spoken ingressively are underlined and in italics. Where available, URLs are stated, as well as the relevant time segment in the files.

\subsection{Ireland}

Illustration of Irish ingressives may be found in the speech of Paddy Malone, the piper of the Irish band The Chieftains, who hails from Dublin. Instances may for instance be heard in the brief documentary 'San Patricio - Behind the scenes', which portrays the making of the San Patricio album (2010), featuring the Chieftains and American guitarist Ry Cooder. The extract below comes from a conversation between Paddy Malone (PM) and Ry Cooder (RC), concerning the San Patricio battalion a group of Irish volunteer soldiers who deserted the US army and fought on the Mexican side in the Mexican-American war (I 846-I 848).

(I) RC: It's a beautiful little song and the lyrics (...) are, if you flip it around, seems to me that (...) the same could be said for these poor Irish soldiers,

[who] are so far from home PM:

PM: That's right

[yeah]

RC: Probably never going back

PM: Yeab (ingressive)

RC: Well, [needless] to say

PM: [Yeah]

PM: $\underline{\text { Yeah }}$ (ingressive)

RC: So for them it's also true

RC: $\underline{Y e a b}$ (ingressive), very much so

RC: You know, Yeah. The diasporic person [is] never gonna get back [there]

PM:

$[\mathrm{Mmm}] \quad[\underline{Y e a h}$

(ingressive)]

Link: http://www.youtube.com/watch?v=54PDlicm_94

Location in link: 7:22-7:4 I 


\subsection{England}

It seems to be particularly difficult to find recorded instances of ingressives from England. However, instances occur in the audio recordings made by the Survey of English Dialects in Patterdale, Westmoreland, Northern England, in I974. The recording consists of a conversation on the topic of gardening, work etc., between the fieldworker, linguist Clive Upton (CU), and the interviewee Edward Blamire (EB), born in 1903.

(2) CU: You do all sorts of other work, now, around the estate

EB: Well, aye. I mow, I mow the la-, mow the lawns. Do fencing. And uh

CU: [inaudible]

EB: Anything what, anything what I can do

CU: Hmm

EB: Aye, Aye (ingressive)

CU: Yeah, Hmhm

EB: That's right

CU: Yeah

Link: http://sounds.bl.uk/Accents-and-dialects/

Survey-of-English-dialects/02 IM-Co908X0005XX-0300VI

Location in link: 4:10-4:30

\subsection{Shetland}

The Shetland Isles, situated in the North Sea, constitute the northernmost part of the UK. The presence of ingressives in Shetland has been documented more extensively (Sundkvist 20I2a, 2012b). The extract below is from a conversation between the author (PS) and a Shetland man (LM) in his 8 os, from Shetland's main town of Lerwick. The interview is part of a corpus collected by the author $2000-2003$ for a study of Lerwick pronunciation, and the discussion concerns the microphone stand.

(3) LM: Yeah, you can't take the nut far enough, that's the thing, yeah PS: No. And then when you keep

LM: You put a washer in, or something like that with

PS: Yeah, I can put that but I [think] when I come home I need to take it

LM:

[Yeah] apart and $[\mathrm{do}]$

[Yeah]

PS: something with it

LM: $\underline{\text { Yeah }}$ (ingressive)

Link: Audio file not made available. 


\subsection{Orkney}

The Orkney Isles are located just off the north coast of Scotland. The excerpt below is taken from data collected by Gunnel Melchers and Arne Kjell Foldvik between I980 and I985. The conversation involves one of the fieldworkers (Arne Kjell Foldvik, AKF) and a farmer from the isle of Westray (WM), whose age is estimated to be between 45 and 50 by Foldvik. The conversation takes place outdoors, and reflects a chance encounter with the local.

(4) AKF: But you got to have them inside all winter

WM: [Oh, yes]

AKF: [pass] the winter

WM: Oh yes, they come in in November

AKF: Umhm

WM: and they're in 'til the first of May

AKF: Silage? Is that $[\ldots]$

WM:

[yes, mostly] silage, yes, that's right, aye (ingressive)

Link: Audio file not made available.

\subsection{Fair Isle}

Fair Isle is a small island in the North Sea, situated halfway between the Orkney and Shetland Isles. Although it is officially part of Shetland, Fair Islanders display a strong local identity, often expressed as being distinct from that of the rest of Shetland. The presence of ingressives within the Fair Isle community was established in Sundkvist 20I2a, b. The excerpt below is from an animated discussion between one local woman (FIF) and two local men (FIMI, FIM2). It was recorded in 1982 by Gunnel Melchers and Arne Kjell Foldvik. For simplicity, word forms and spelling have been adjusted to Standard English in the extract.

(5) FIMr: But someone, for the funeral, someone, someone who belonged to the body [=person] who was dead, they had to get around to every house, like

FIM2: Invited every house [to the funeral]

FIMI:

$[(\ldots)$ invite to the $]$ funeral

FIF: Yeah

FIMI: $\underline{\text { Yeab }}$ (Ingressive)

FIM2: Yeah

Link: Audio file not made available. 


\subsection{Cape Breton}

Turning the focus across the North Atlantic, instances of ingressives may also be found from North America. The example below is from a documentary about the Irish heritage of Cape Breton, Nova Scotia, Canada: 'The Irish in Cape Breton I7I3-I990' (The Irish In Cape Breton 3 of 6, I990, produced, directed and narrated by Kenneth Donovan). The interviewer is Kenneth Donovan (KD), a Parks Canada historian; the interviewee is Loretta Donovan (LD), an elderly lady.

(6) KD: And how many uh ... children were in your family, in your father and mother's family?

LD: Nine, we had six boys and three girls

KD: Six boys [and] three girls?

LD: [Yes]

LD: And I'm the only girl left, but I have two brothers in the States

KD: Right

LD: My older brother

KD: Yeah

LD: Not my older brother [name], $\underline{\text { Yeah }}$ (ingressive), and one is 89 and the other is 84

Link:http://www.youtube.com/watch?v=JsmyRknWUVo\&feature $=$ relmfu

Location in link: $07.25-07: 42$

\subsection{Newfoundland}

As to Maritime Canada, examples of ingressives may be found for instance in the online archive of Memorial University of Newfoundland. The archives reveal the presence of ingressive speech in several locations within Newfoundland. The example presented below is from Lower Cove. The conversation took place between interviewer Lisa Wilson (LW) and interviewee Mamiellen Noseworthy (MN) on June 7, 2010, and concerns local craft.

(7) LW: Doreen just spent 'bout half an hour showing me, just a sample, how to do a pleat

MN: Yeah

LW: And, she's going quite fast [laughter], and there's no way I could do that without having to watch, a lot

MN: Right

LW: And then practice a lot

MN: Yeah 
LW: So, observe, observe, observe, and then practice, practice, practice

MN: Yeab (ingressive), yeah

Source: Noseworthy, Mamiellen. Lisa Wilson interviewing Mamiellen Noseworthy, June 7, 20I0, Lower Cove, Newfoundland. Archive ID: $\mathrm{ICHTS}_{3}$ Iо

Link: http://collections.mun.ca/index.php

Location in link: 4:30-4:55

\subsection{British Columbia}

While previous sources have pointed towards the existence of ingressive speech in Maritime Canada, few have mentioned the possibility for the western parts of the country. The token below is from a young female from British Columbia. It occurs in an episode of the crime show ' 48 hours' titled 'Highway of Tears', which deals with a series of disappearances and homicides along a part of the Trans-Canada highway system supposedly known by some locals as the 'highway of tears'. However, only one ingressive token occurs in the material, on reported speech within a conversation between the reporter $(\mathrm{R})$ and the female (Jordanne Bolduc, JB).

(8) R: What did she say to you?

JB: She was just like shocked, she's like: really? You're going? And I was like: yeah (ingressive), I'm going

JB: And [pause] she kinda begged me, and then I was just well you can come with us and she said 'no', She wanted to stay there with her tent, for it to be safe

Link: https://www.youtube.com/watch?v=xDQDQqDR8SI

Location in link: $13: 30-13: 45$

\subsection{The Nordic languages}

The existence of ingressive speech is well documented for Swedish, Norwegian, and Danish. However, fewer samples appear to be easily available for Insular Scandinavian, such as Icelandic and Faroese. The following section thus presents examples concerning Icelandic and Faroese, as well as the Swedish word jo/ju, commented on earlier.

\subsubsection{Icelandic}

Icelandic ingressives are amply illustrated in the TV show Silfur Egils. In the excerpt below, the host Egill Helgason is talking to a book keeper, 
Bragi Kristjónsson (aka Bragi bóksali). The conversation concerns a photographic book.

(9) BK: These are his parents.

EH: Yes.

BK: Haraldur Guðmundsson, master carpenter, and the mother.

EH: $\underline{\text { Yes }}$ (ingressive).

BK: And his brother Leifur who wrote the poem there "The young poets write verses..."

EH: “...without being able to".

BK: “...without being able to/ In the Public house ${ }^{\mathrm{I}}$ I get daily meals/ without eating them".

$\mathrm{EH}$ : Yes, yes, yes (ingressive) Yes-yes.

BK: But this brother of his, Magnús Haraldsson

$\mathrm{EH}: \underline{\text { Yes }}$ (ingressive).

BK: he died in a car accident.

Link: http://www.youtube.com/watch?v=5JMCuKGy-zM

Location in link: $\mathrm{I}: \mathrm{I} \mathrm{I}-\mathrm{I}: 4 \mathrm{I}$

\subsubsection{Faroese}

Faroese ingressives may similarly be illustrated with material from a talk show. The interviewer below is journalist and show host Høgni í Jákupsstovu (speaking with a Tórshavn dialect); the interviewee is artist Tróndur Patursson (with a Kirkjubø dialect).

(Iо) HJ: Yes, welcome Tróndur Patursson.

TP: Thank you.

HJ: 40 years since you first were at the art museum (= Listasavn Føroya, National Gallery).

TP: Yes, yes (ingressive).

HJ: You do it like the queen, [hold] a 40 year anniversary?

TP: Well, yes, yes-yes. I suppose it is. I suppose it is. Yes (ingressive)

HJ: How was it to be back at the art museum, after that conflict [that you were a part of]?

TP: Yes, yes, the art museum is a truly outstanding building (.)

Link: http://www.youtube.com/

watch? $v=n q R q w 8 F y N R k \&$ feature $=r e l m f u$

Location in link: 3:05-3:30

r The word Alpýðuhúsið literally means 'the house of the public or the public house'. However this is not the same as a public house as abbreviated into 'pub' but rather a type of communal guesthouse (Friðrik Sólnes, p.c.). 


\subsubsection{Swedish 'jo'/'ju'}

As pointed out previously, the word jo/ju ('yes') in Swedish may be spoken on a pulmonic ingressive airstream; in such instances it may be generally characterized as a voiceless bilabial fricative or approximant. This pronunciation is often associated with the northern parts of Sweden, and one individual commonly mentioned with regard to it is former alpine skier Ingemar Stenmark, whose laconic conversational style was popularly thought to fit well with the brief reply of a jo/ju. The discussion below occurs in an episode of the TV show 'Mästarnas mästare', whose participants are former top athletes. It concerns an annoying interview with a journalist who prematurely made the suggestion that Stenmark's career had come to an end. Stenmark (IS) is talking with Peter ("Pekka") Lindmark (PL), a former ice hockey goal keeper.

(I I) PL: No, but really, it must be horrible to get a [expression meaning 'we thank you for the time you have been a skier'] and then you go on winning another 20

IS: Yeah

PL: Oh, [it] is like kicking the legs out from under you

IS: $\quad$ [Yeah]

IS: I really felt like, it would have been better to quit long, long before, before I had, just when I had reached the top

PL: Yes, because then you were, exactly, then you would have become immortal, but

IS: [Yes, then I would have]

PL: [But you] really were outstanding, for very many years

IS: Yeah

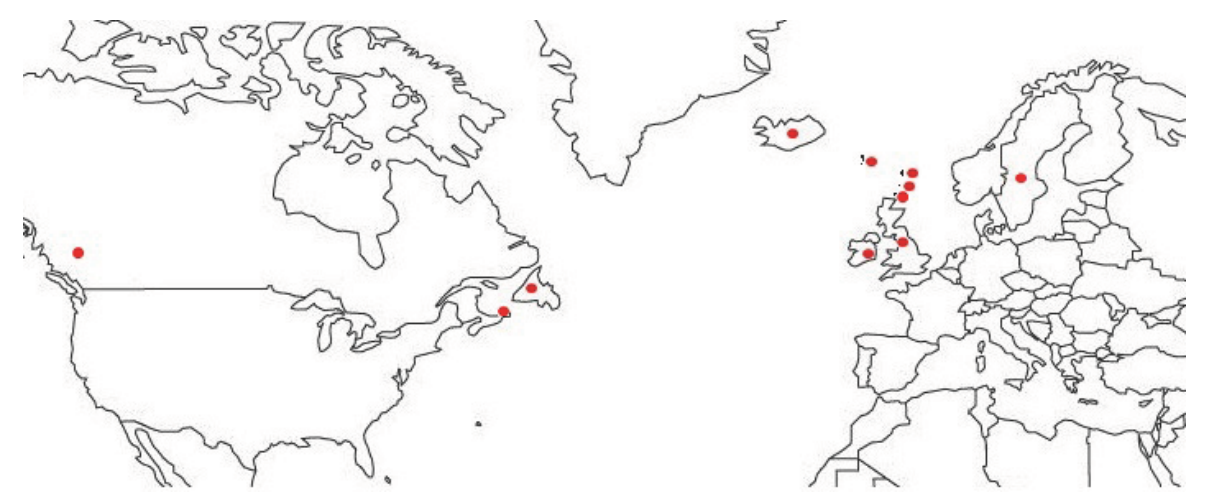

Figure 1. Documentations of pulmonic ingressive speech in section 4 . 
PL: And won and won and won

IS: Yeah (Ingressive; bilabial fricative)

Link: http://www.youtube.com/watch?v=fHE9XgXNwfo\&feature=related Location in link: 8:57-9:2I

\subsection{Summary: Audio and video documentation within the North Atlantic region}

The range of localities for which evidence of pulmonic ingressive speech, based on audio and visual material, has been presented in section 4 is summarized in Figure I below. A (red) dot in the map signifies that an illustration has been provided for the locality in question. Regarding access to relevant sound files, URLs are available and provided for Ireland, England, Cape Breton, Newfoundland, British Columbia; and also Icelandic, Faroese, and Swedish. For Shetland, Orkney, and Fair Isle no URLs are available. Further linguistic analysis of the ingressive tokens presented, including their discourse function, falls outside the scope of the present study. It should be noted, however, that all tokens in section 4 constitute expressions for 'yes' provided as feedback during a conversation.

\section{Illustration of stereotypes, popular notions}

Pulmonic ingressive speech is associated with a range of stereotypes and popular mythology. A common notion in localities where it occurs seems to be that it is unique to that particular area; general awareness of its wider distribution seems fairly limited. This self-perceived exclusivity, or at least typicality, applies not only to Swedes and Norwegians but also to several English-speaking localities. The following media clips illustrate the conception that it is unique to or at least characteristic of a particular region, that it may be misunderstood by outsiders, and that it consequently may need to be explained to them.

The part of North America which seems most commonly discussed with regard to ingressive speech is coastal Maine. In particular, it tends to be mentioned in conjunction with the word ayuh or ayup ('yes'). Similar anecdotes may be encountered for Maine as from Scandinavia, in which newcomers are bewildered and confused by the phenomenon. One such anecdote, illustrated in the link below, concerns a medical doctor from Kentucky, who was working in Down East Maine, a part of coastal north-eastern Maine which borders on Canada. The doctor asks a local patient if he is OK, to which he answers ayuh (pronounced 
as a voiced ingressive). The doctor is puzzled by the patient's apparent gasp and becomes concerned about his health, not realizing that it in fact represents a 'yes' to the question if he is OK.

Link: http://dailydevotions.org/index.php/infoDaily-Devotions/20I2/og/I6I I https://www.youtube.com/watch?v=hLU47 YkclSM

A second case in point concerning coastal Maine is provided by humourist Tim Sample. This comes from a live stage show, based partly on an audio record: How to Talk Yankee: A Downeast Foreign Language Record featuring Bob Bryan and Tim Sample. During the show, Sample and Bryan discuss several local words and expressions, including 'ayuh'. As the conversation is fairly long, and digresses somewhat at several points, only relevant parts are extracted below. Sample begins by suggesting to the audience that there are several ways of saying 'ayuh', including both egressive and ingressive variants. As to the more exotic ingressive variant, Sample discusses its use, implying that it forms part of a greeting, and provides explicit instruction and a drill to the audience on how to perform it. He starts:

(I2) So I'll tell you one thing that will fool even a native occasionally. You can learn this, you can learn this even if you're driving a Volvo (...) (...) This is the 'Yankee reverse nod with inhalation'. This is how native Yankees communicate with each other on the road.

Sample goes on to give an instruction:

(I3) Try this: you inhale like that, and throw your head back at the same time.

He finally illustrates its usage, as part of greeting a local:

(I4) So you're driving down the road wishing you was from here. You see old Bert and his '67 Chevy pickup truck. (...). So, what you wanna do, you see Bert over the hill. You [Sample inhales and throws back his head, as instructed] like that. He does it too, see. And for a moment there, you're bonded.

Link: https://www.youtube.com/watch?v=hTz9LBxNai4

Location in link: ०:००-5:००; record also available for purchase (see list of references).

Reference to ingressive speech is also to be found in Maritime Canada. Some instances indicate that it is believed to be specific to the region. 
As an example, a host at a local radio station on Prince Edward Island made the following call for listeners to phone in their 'islanderisms':

(I 5$)$ Now, on to tonight's topic [...]. I have a favour to ask of you. I need you guys to call me in with your 'Islanderisms'. What I mean by that. 'Islanderism', definition = something that is specific to our native tongue. Example: 'slippy', as opposed to 'slippery'. The sound of an inhalation, as opposed to 'yes', and what I mean by that is: yeah (ingressive). You know what I mean. Stuff like that. I want you guys to give me a call with your examples, and we can see just how many islanderisms there are.

Link: http://www.youtube.com/watch?v=c6 5 CxooxenA

Location in link: ०:०8-0:44

Turning to Norway, popular commentary on ingressive speech is fairly frequent. In a self-sarcastic manner, 'Song about integration' (as featured in the comedy show 'Sex og SingelSiv' broadcast on VGTV) plays on stereotypes of Norwegian culture and behaviour, with a focus on aspects that may be unfamiliar and seem peculiar to immigrants. Among the many stereotypes drawn upon is pulmonic ingressive speech:

(I6) (...)

And if you talk to strangers on the bus you are a jerk And when you say 'yes', so say it on ingressive speech

Link: http://www.youtube.com/watch?v=rBvm3IpRzZ8

As mentioned, the Swedish word jo/ju ('yes') may be uttered as a voiceless bilabial fricative or approximant, on a pulmonic ingressive airstream. This feature appears to be more common in northern Sweden, and is stereotypically associated with it (Eklund 2008: 262-263). Popular commentary may be found online. One example is provided by former ice hockey player Jonas Bergqvist, who was born in southern Sweden (Ängelholm, Scania) but moved to a more northerly part (Leksand, Dalcarlia) to attend high school. He recalls that he adopted ingressive jo/ju among other features when moving north, and that it was overtly commented on when returning south, reflecting its distinct regional marking:

(I7) (...) and that's how it was, when I moved there, then I had that real Scanian dialect, and said: "one and two and three"[Scanian accent] and "are you stupid?" and so on, and everyone said 'what?' all the time. So in some way it was only natural that I tried to make 
myself understood, and then it started becoming "one and two and three." [clear standard]. Then sometimes a jo/ju (voiceless ingressive bilabial fricative) would enter [into my speech], and then they nearly split their sides laughing when I returned home in the summer.

Link: http://www.youtube.com/watch?v=9T-NTI5 $\mathrm{Ql}_{7} \mathrm{Y}$

Location in link: I7:40-1 8:03

\section{Conclusion}

Although pulmonic ingressive speech may initially admittedly seem like a fairly peripheral matter, upon further consideration the phenomenon is clearly significant in several ways. Its typological status remains a topic of debate, with proposals ranging from 'highly marked' to 'neglected universal'. Significantly for our purposes, its pattern of distribution among regional Englishes has not been sufficiently established; although it has been claimed to occur in a range of regions, there has been a glaring lack of objective evidence. What is more, it is a feature which may possibly reveal historical connections among Englishes across the North Atlantic region. Unfortunately, it has proved challenging to elicit and record pulmonic ingressive speech in many localities. In response, previous researchers have tried several alternatives to standard sociolinguistic methods, including observational methods (Peters I98I) and wide-scope searches of a broad range of written sources (Eklund 2008). In this paper we explored a further alternative, namely the World Wide Web and the many sources of information to which it provides access. Claims were reviewed that ingressives may be hard to study through the media, partly because relevant speaker groups are not well represented therein (Thom 2005; Salö \& Hanell 2009). While this may be true to some extent, the massive expansion of the WWW has opened up new possibilities in this regard and necessitates a re-examination of the potential of the media, broadly defined. In this paper a collection of audio and video clips was presented; in addition excerpts from research data sets were provided. This contributed documentation for the existence of pulmonic ingressive speech in an additional set of Englishes. Despite the moderate total number of tokens, ingressive speech was illustrated for both genders, in each case on a brief 'yes' response. Furthermore, illustrations could also be found of the many popular notions surrounding ingressive speech.

Owing to the highly transient nature of the medium and technology involved, it is difficult to predict the future range of applications and 
benefits of the WWW for the study of spoken language (cf. Crystal 20I3: 257, 273). At this stage, however, several possibilities as well as potential limitations are discernible. As to the many possibilities, while spoken language so far clearly is less well represented than written language on the WWW, there is reason to believe that both the amount and the proportion of video and sound material will increase as the WWW continues to grow and technology develops (Crystal 2013: 9; Ess \& Consalvo 20II: 2). Since the expansion of the internet over the last ten years has been the greatest in Africa, the Middle East and Latin America, there is also reason to be hopeful that it may provide a source of evidence for pulmonic ingressive speech in these parts of the world, for which objective evidence is completely lacking. What is more, linguists are gradually beginning to realize the formidable, largely unexplored pedagogical potentials of the WWW with regard to spoken language. Squires and Queen (20II: 27) outline some of the benefits of media collections for the teaching of linguistics, which include the ability to illustrate particular features of spoken language.

A number of limitations are however apparent. The time factor is clearly significant. The set of clips presented in this paper was located through a combination of idle web surfing and purposeful, directed searches by the present author, sporadically as well as during more sustained intervals stretching over a total period of $3-4$ years. Some were also obtained through kind suggestions by others. It must therefore be acknowledged that the compilation of even a relatively small collection of material is time-consuming, and perhaps best approached as a longterm project. A second serious limitation is the transience of the medium. URLs are notoriously short lived, and there is no guarantee that published web links will even be alive at the time of publication (Crystal 20I3: 257; Squires \& Queen 20I I: 229). It is therefore of course preferable to save material onto more permanent storage, which, however, leads into other issues such as storage space and copyright (Crystal 20I3: 273; Squires \& Queen 20II: 229). In addition, it is also possible that in the future internet sites providing useful material to a greater extent will require their users to pay. On the whole, however, echoing Crystal's remark that "(...) the sheer scale of the present Internet, let alone its future telecosmic incarnations, has convinced me that we are on the brink of the biggest language revolution ever" (2013: 274-275), there is good reason to be optimistic that the World Wide Web will prove a useful tool for exploring a range of additional features of spoken English, reflecting the value of the internet in ways far beyond those originally envisaged. 


\section{Appendix: Excerpts in the original (Nordic languages)}

Icelandic (example 9)

BK: Sko, petta eru foreldrar hans.

EH: Já.

BK: Haraldur Guðmundsson trésmíðameistari og móðirin.

EH: Já (ingressive).

BK: Og Leifur bróðir hans sem orti parna vísuna "Ungu skáldin yrkja kvæði...”.

EH: “...án pess að geta pað”.

BK: “...án pess að geta pað/ í Alpýðuhúsinu er ég í fæði/ án pess að éta pað”.

EH: Já, já, já (ingressive), jájá.

BK: En sko pessi bróðir hans, Magnús Haraldsson.

EH: Já (ingressive).

BK: Hann dó í bílslysi.

Faroese (example 10)

Hógni: Ja, vælkomin, Tróndur Patursson

Tróndur: Takk fyri tað

Hógni: 40 ár siðani tú fyrsti ferð vart á Listasavninum.

Tróndur: Ja, ja (ingressive).

Hógni: Tað er [tú gjert?] sum drottningin, 40 árs jubileum.

Tróndur: Ná, ja, jaja, tað er nakað um tað. Tað er nakað um tað. Ja (ingressive)

Hógni: Tú, hvussu tað at vera aftur, aftaná hetta her stíði hjá tykkum? Tróndur: Ja, ja, Listasavnið er, er ein heilt einastandandi bygningur. (...)

Swedish (example 11)

PL: Nej, men alltså, det måste vara fan ruggigt att få ett tack för den tid som har varit ungefär och så vinner man 20 till

IS: Jo

PL: Åh, [det] är som att sparka undan bena

IS: [jo]

IS: Egentligen hade man ju lust, det hade varit bättre att sluta långt, långt innan, innan man hade, precis när man hade kommit upp på toppen

PL: Ja, för då va man, precis, då hade du varit odödlig, men

IS: [Ja, då hade jag]

PL: [men du] var ju hur bra som helst hur många år som helst

IS: Jo 
PL: Och vann och vann och vann

IS: Jo (ingressive, bilabial fricative)

Norwegian (example 16)

Song about Integration: Norwegian lyrics:

(...)

Og snakker du med fremmede på bussen er du dust

Og når du sier “ja” så si det på innoverpust.

(...)

Orthographic transcription from: http://www.youtube.com/ watch? $=$ =rBvm3IpRzZ8

Swedish (example 17)

[...] Och det var ju så när man flyttade dit, då hade jag den här riktigt skånska dialekten, va, och sa "itt och två och tre" och "e du dum i huvudet" och så där, och alla sa 'va' hela tiden, så då blev det liksom på nåt sätt att man försökte göra sig förstådd va, och då började det bli "ett och två och tre och'. Sen kom det in nåt jo/ju (ingressive) ibland och så där va, och då skattade de ihjäl sig när man kom hem på sommaren. [...]

\section{Acknowledgements}

I would like to thank several people who have provided useful comments and discussions on ingressive speech, translations, and in one case links to media clips; in particular I am grateful to Edit Bugge, Daniel Davis, Clelia LaMonica, Gunnel Melchers, and Friðrik Sólnes.

\section{References}

Clarke, S. \& Melchers, G. (2005). Ingressive discourse particles across borders: Gender and discourse parallels across the North Atlantic. M. Filppula, J. Klemola, M. Palander \& E. Pentitilä (eds) Dialects across Borders: Selected papers from the IIth international conference on methods in dialectology (Methods XI), Joensuu, August 2002. Amsterdam/Philadelphia: John Benjamins, $5 \mathrm{I}-72$.

Consalvo, M. \& Ess, C. (eds) (201 I). The Handbook of Internet Studies. Oxford: Blackwell Publishing Ltd.

Crystal, D. (2013). Language and the Internet. Cambridge Books Online. Cambridge: Cambridge University Press.

Donovan, K. (Producer, Director, Narrator) (1990). The Irish in Cape Breton 
I7I3-I990 (part 3 of 6). Sydney, Nova Scotia, Canada: Irish Benevolent Society. Retrieved from: http://www.youtube.com/watch?v=JsmyRknWUVo Eklund, R. (2007). Pulmonic ingressive speech: A neglected universal? Proceedings of Fonetik 2007, Stockholm, TMH-QPSR, KTH, 50, 2 I-24.

. (2008). Pulmonic ingressive phonation: Diachronic and synchronic characteristics, distribution and function in animal and human sound production and in human speech. Journal of the International Phonetic Association 38, 235-324.

Ess, C. \& Consalvo, M. (20II). Introduction: What is "Internet Studies"? M. Consalvo \& C. Ess (eds) The Handbook of Internet Studies. Oxford: Blackwell Publishing Ltd, I-8.

Hanell, L. \& Salö, L. (2009, June). Säg jo och andas in - samtidigt. Språktidningen 3, I4-I9.

Peters, F.J. (I98I). The Paralinguistic Sympathetic Ingressive Affirmative in English and the Scandinavian Languages. (Unpublished doctoral dissertation). New York University, New York.

Pitschmann, L.A. (I987). The linguistic use of the ingressive air-stream in German and Scandinavian languages. General Linguistics 27, I 53-I6I.

Sample, T. (I99I). How to Talk Yankee: A Downeast Foreign Language Record Featuring Bob Bryan and Tim Sample. Down East Publisher.

Shorrocks, G. (2003). Pulmonic ingressive speech in Newfoundland English: A case of Irish-English influence? H.L.C. Tristram (ed.) The Celtic Englishes III. Heidelberg: Universitätsverlag Winter, 374-389.

Squires, L. \& Queen, R. (20I I). Media clips collection: Creation and application for the linguistics classroom. American Speech 86, 220-234.

Steinbergs, R. (I993). The Use of the Paralinguistic Sympathetic Ingressive Affirmative in Speakers of English in the St. John's, Newfoundland Area. (Unpublished master's dissertation). Memorial University, St. John's, Newfoundland, Canada.

Sundkvist, P. (20I2a). Pulmonic ingressive speech in Shetland English. World Englishes 3 I, 434-448.

- (2012b). Pulmonic ingressive speech in the Shetland Isles: Some observations on a potential Nordic relic feature. Nordic Journal of English Studies I I, I 88-202.

Thom, E.J. (2005). The Gaelic Gasp and its North Atlantic Cousins: A Study of Ingressive Pulmonic Speech in Scotland. (Unpublished master's dissertation). University College London, London, UK. 
